\title{
Pemetaan Kualitas Permukiman dengan Menggunakan Penginderaan Jauh dan SIG di Kecamatan Batam Kota, Batam
}

\author{
M. Farizki ${ }^{1}$ dan Wenang Anurogo ${ }^{2}$
}

\author{
Email Korespondensi:mfarizki10@gmail.com \\ Diterima: 1 Desember 2017 /Disetujui: 1 Februari 2017/ Publikasi online: 31 Maret 2017 \\ (c) 2017 Fakultas Geografi UGM dan Ikatan Geograf Indonesia (IGI)
}

Program Studi Teknik Geomatika, Politeknik Negeri Batam, Batam Kepulauan Riau ${ }^{1,2}$

\begin{abstract}
Abstrak Permukiman adalah bagian dari lingkungan hidup yang berfungsi sebagai lingkungan tempat tinggal. Kondisi dari suatu permukiman sangat mempengaruhi kelangsungan kehidupan dan kesejahteraan makhluk hidup di permukiman tersebut. Untuk mengetahui kualitas permukiman di Kecamatan Batam Kota dibutuhkan parameter-parameter penentu yang di interpretasi dari citra resolusi tinggi (Google Earth). Untuk membantu proses analisis dengan memanfaatkan teknologi penginderaan jauh dan untuk pemetaan menggunakan software SIG. Metode yang digunakan adalah metode pengharkatan (scoring), tumpang susun (overlay). Hasil dari overlay tersebut adalah peta kualitas permukiman di kecamatan Batam Kota, Kota Batam. Dari penelitian ini dapat diketahui bahwa permukiman di Kecamatan Batam Kota dengan kualitas baik dengan luas $476.88 \mathrm{Ha}$, kualitas sedang dengan luas $650 \mathrm{Ha}$, dan kualitas buruk dengan luas 48.89 Ha. Dari hasil tersebut permukiman di Kecamatan Batam Kota didominasi oleh permukiman dengan kualitas sedang.
\end{abstract}

Kata kunci: Kualitas permukiman, Penginderaan jauh, SIG, Pembobotan, Tumpang Susun

\begin{abstract}
The neighborhood is part of the environment that serves as a neighborhood residence. The condition of a settlement extremely affects to the continuity of life and the well-being of living creatures in the neighborhood. To find out the quality of the neighborhoods in districts of Batam City required parameters in determining the interpretation of high-resolution images (Google Earth). To help the analysis process by making use of remote sensing technology for the mapping, and using software SIG. The Method is using score (scoring), and stack bundles (overlay). The result of the overlay mapped quality neighborhoods in districts of Batam city, Batam city. From this research it can be known that settlements in Batam City with good quality with extensive $476.88 \mathrm{Ha}$, better quality with an area of $650 \mathrm{Hectares,} \mathrm{and} \mathrm{bad} \mathrm{quality} \mathrm{with} \mathrm{extensive} 48.89$ $\mathrm{Ha}$. The results of the neighborhoods in districts of Batam City are dominated by the neighborhoods with better quality.
\end{abstract}

Keywords: environmental quality, remote sensing, GIS, Scoring, Overlay

\section{PENDAHULUAN}

Laju pertumbuhan penduduk di daerah perkotaan yang semakin meningkat selalu memberi perubahan, salah satunya adalah perubahan pada tingkat kualitas lingkungan. Tingginya pertumbuhan penduduk baik yang disebabkan oleh pertumbuhan alami maupun adanya perpindahan penduduk dari desa ke kota. Pertumbuhan penduduk yang cepat menyebabkan semakin besarnya kebutuhan ruang untuk tempat tinggal sehingga menyebabkan berkembangnya permukiman tidak terkontrol, terutama hunian liar atau permukiman kumuh yang dapat mengakibatkan menurunnya kualitas permukiman, khususnya didaerah perkotaan. Kota merupakan pusat dari permukiman yang relatif besar dan menjadi pusat kegiatan manusia dan menawarkan kesempatan untuk mendapatkan hidup lebih baik dari pada di daerah pedesaan (Prasetyo et.al, 2013). Oleh sebab itu diperlukan metode yang mampu mengatasi kendala tersebut. Salah satu teknik yang digunakan adalah dengan memanfaatkan teknologi penginderaan jauh dalam penentuan kualitas permukiman. Citra penginderaan jauh adalah teknologi yang mampu menyediakan data atau informasi, mempunyai kemampuan dalam pengumpulan data atau informasi secara cepat, akurat dan mutakhir. Salah satu teknologi yang digunakan adalah dengan menggunakan Google Earth. Ada beberapa informasi kualitas permukiman yang dapat diperoleh dengan mengkaji citra penginderaan jauh yaitu kepadatan permukiman, tata letak bangunan, lebar jalan masuk, lokasi permukiman, kondisi masuk jalan, dan pohon pelindung.

Proses identifikasi dilakukan dengan interpretasi visual memanfaatkan perangkat sistem informasi geografi (SIG), sehingga menghasilkan informasi baru yaitu peta kualitas permukiman.

\section{METODE PENELITIAN}

Penelitian ini data yang digunakan adalah citra resolusi tinggi (Google Earth) dari Kecamatan Batam Kota, Kota Batam. Penelitian ini menggunakan metode interpretasi visual dan overlay dari parameter yang digunakan. Interpretasi citra merupakan kegiatan mengkaji foto udara atau citra yang bertujuan untuk 
menganalisis objek dan menentukan arti pentingya objek tersebut (Ambarasakti, 2013). Interpretasi data dalam penginderaan jauh dilakukan secara digital bagi data numerik dan data secara manual bagi data visual. Interpretasi data penginderaaan jauh dilakukan untuk mengubah data numerik atau data visual menjadi informasi bagi keperluan tertentu. Ada tiga rangkaian yang diperlukan pada pengenalan objek, yaitu deteksi, identifikasi, dan analisis (Kurniadi, 2014). Deteksi adalah pemantauan terhadap suatu objek pada citra. Identifikasi adalah upaya menentukan suatu objek yang telah dideteksi. Pada tahap analisis dilakukan setelah semua data dikumpulkan. Untuk menginterpretasi suatu objek pada citra harus memperhatikan unsurunsurnya. Scoring adalah pemberian bobot / nilai pada setiap faktor - faktor tertentu dengan cara memberi bobot pada masing-masing parameter untuk menentukan tingkat kemampuan berdasarkan kriteria yang telah ditentukan. Sehingga dengan pemberian bobot kita dapat menentukan tingkat kemampuan berdasarkan tingkatan-tingkatan dari parameter tersebut (Sholahuddin, 2014).

\section{Kepadatan Permukiman}

Kepadatan permukiman suatu blok permukiman dihitung berdasarkan jumlah luas seluruh atap dibagi dengan luas blok permukiman dalam satuan unit permukiman, sehingga dari hasil perhitungan tersebut dapat diketahui perbandingan antara penggunaan lahan prmukiman dan non permukiman di permukiman tersebut. Dari perhitungan kepadatan permukiman kemudian diklasifikasikan berdasarkan Tabel 1.

Tabel 1. Klasifikasi Kepadatan Permukiman

\begin{tabular}{lll}
\hline Kriteria & Kriteria & $\begin{array}{l}\text { Harkat } \\
\text { (Score }\end{array}$ \\
\hline $\begin{array}{l}\text { Kepadatan rumah rata-rata } \\
\text { pada permukiman jarang } \\
(<40 \%)\end{array}$ & Baik & 3 \\
$\begin{array}{l}\text { Kepadatan rumah rata-rata } \\
\text { pada permukiman sedang } \\
(<40 \%-60 \%)\end{array}$ & Sedang & 2 \\
$\begin{array}{l}\text { Kepadatan rumah rata-rata } \\
\text { pada permukiman Padat } \\
(>60 \%)\end{array}$ & Buruk & 1 \\
\hline
\end{tabular}

\section{Peta Tata Letak Bangunan}

Parameter ini di nilai berdasarkan keteraturan letak, dan besar/kecilnya bangunan. Bangunan yang memiliki ukuran relatif sama dan letaknya mengikuti pola tertentu, maka dikelompokkan pada satuan unit pemetaan yang sama. Klasifikasi penilaian pola tata letak bangunan terdapat pada Tabel 2 .
Tabel 2. Tata Letak Bangunan

\begin{tabular}{lll}
\hline Kriteria & Klasifikasi & $\begin{array}{l}\text { Harkat } \\
\text { (Score) }\end{array}$ \\
\hline $\begin{array}{l}\text { Jika lebih dari atau sama } \\
\text { dengan 50\% bangunan- } \\
\text { bangunan sedang tertata } \\
\text { teratur }\end{array}$ & Baik & 3 \\
$\begin{array}{l}\text { Jika 25\% - 50\% bangunan } \\
\text { tertata teratur }\end{array}$ & Sedang & 2 \\
$\begin{array}{l}\text { Jika ( }>25 \% \text { ) sebagian be- } \\
\text { sar bangunan kurang tertata } \\
\text { teratur }\end{array}$ & Buruk & 1 \\
\hline
\end{tabular}

\section{Lebar Jalan Masuk}

Lebar jalan masuk yang dimaksud adalah lebar jalan yang menghubungkan jalan lingkungan dari suatu permukiman dengan jalan utama atau jalan arteri. Klasifikasi yang digunakan untuk penilaian lebar jalan masuk terdapat pada Tabel 3.

Tabel 3.Klasifikasi Lebar Jalan Masuk

\begin{tabular}{lll}
\hline Kriteria & Klasifikasi & $\begin{array}{l}\text { Harkat } \\
\text { (Score) }\end{array}$ \\
\hline $\begin{array}{l}\text { Jika lebar jalan }>6 \mathrm{~m} \text { dapat } \\
\text { dilalui 2-3 mobil }\end{array}$ & Baik & 3 \\
$\begin{array}{l}\text { Jika lebar jalan } 4-6 \mathrm{~m} \text { dapat } \\
\text { dilalui 1-2 mobil }\end{array}$ & Sedang & 2 \\
Jika lebar jalan $<4 \mathrm{~m}$ & Buruk & 1 \\
\hline
\end{tabular}

\section{Lokasi Permukiman}

Parameter lokasi permukiman dinilai dari letak jauh atau dekatnya suatu blok permukiman terhadap sumber polusi ini bisa berasal dari terminal, pabrik, kawasan perdagangan dan jasa atau jalan utama. Hal ini berhubungan dengan tingkat kualitas udara di permukiman tersebut. Pada tahap interpretasi untuk penilaian lokasi permukiman melalui citra, dinilai secara kualitatif. Klasifikasi yang digunakan terdapat pada Tabel 4 .

\section{Kondisi Jalan Masuk}

Keadaan jalam masuk permukiman dapat diketahui dari jenis bahan pengeras (aspal atau semen) sehingga untuk memberikan penilaian melalui citra dengan memperhatikan rona dari obyek tersebut. Klasifikasi yang digunakan untuk penilaian kondisi jalan masuk terdapat pada Tabel 5.

\section{Pohon Pelindung}

Pohon pelindung adalah pohon yang terdapat pada kanan kiri jalan masuk pada blok permukiman. Kenampakan obyek pohon pelindung yang ditampilkan pada citra dapat dikenali melalui warna dari obyek tersebut. Klasifikasi yang digunakan terdapat pada Tabel 6. 


\begin{tabular}{|c|c|c|}
\hline \multicolumn{3}{|c|}{ Tabel 4. Lokasi Permukiman } \\
\hline Kriteria & Klasifikasi & $\begin{array}{l}\text { Harkat } \\
\text { (Score) }\end{array}$ \\
\hline $\begin{array}{l}\text { Jika lokasi permukiman jauh } \\
\text { dari sumber polusi (termi- } \\
\text { nal, pabrik, pasar ) dengan } \\
\text { jarak } \pm 5 \mathrm{~km} \text { dan masih } \\
\text { dekat dengan kota. }\end{array}$ & Baik & 3 \\
\hline $\begin{array}{l}\text { Jika lokasi permukiman } \\
\text { tidak terpengaruh secara } \\
\text { langsung dengan kegiatan } \\
\text { sumber polusi dengan jarak } \\
\pm 3 \mathrm{~km} \text { dari lokasi lingkun- } \\
\text { gan }\end{array}$ & Sedang & 2 \\
\hline $\begin{array}{l}\text { Jika lokasi permukiman } \\
\text { dekat dengan sumber polusi } \\
\text { udara, maupun suara atau } \\
\text { bencana alam dengan jarak } \\
\pm 1 \text { km dari lokasi per- } \\
\text { mukiman }\end{array}$ & Buruk & 1 \\
\hline
\end{tabular}

\begin{tabular}{lll}
\hline \multicolumn{3}{c}{ Tabel 5. Kondisi Jalan Masuk } \\
\hline Kriteria & Klasifikasi & $\begin{array}{l}\text { Harkat } \\
\text { (Score) }\end{array}$ \\
$\begin{array}{l}\text { Jika }>50 \% \text { jalan pada blok } \\
\text { permukiman tersebut telah } \\
\text { diaspal atau semen }\end{array}$ & 3 \\
$\begin{array}{l}\text { Jika 25\% - 50\% jalan pada } \\
\text { blok permukiman tersebut } \\
\text { belum diaspal atau semen }\end{array}$ & Sedang & 2 \\
$\begin{array}{l}\text { Jika }<25 \% \text { jalan pada blok } \\
\text { permukiman tersebut telah } \\
\text { diaspal / disemen }\end{array}$ & Buruk & 1 \\
\hline \multicolumn{2}{c}{ Tabel 6. Pohon Pelindung } & \\
\hline $\begin{array}{l}\text { Kriteria } \\
\text { Klasifikasi }\end{array}$ & $\begin{array}{l}\text { Harkat } \\
\text { Jika memiliki pohon pelind- }\end{array}$ \\
$\begin{array}{l}\text { Jika tidak memiliki pohon } \\
\text { pelidung }\end{array}$ & Baik & 2 \\
\hline
\end{tabular}

\section{Pembobotan Parameter Dari Hasil Interpretasi Visual Citra}

Pemberian bobot ini diberikan pada setiap parameter sesuai dengan besarnya tingkat pengaruh terhadap kualitas lingkungan permukiman. Nilai pada setiap parameter penentu kualitas permukiman ditentukan berdasarkan pembobotan dengan beberapa kategori, terdiri dari klas baik (pemberian skor 3), sedang (pemberian skor 2) dan buruk (pemberian skor 1). Nilai bobot tersebut, nantinya akan dikalikan dengan nilai harkat masing-masing parameter. Selanjutnya, hasil perkalian ini nantinya akan dijumlahkan untuk mendapatkan total harkat parameter dari citra. Rumus yang digunakan untuk mencari total harkat sebagai berikut :

HT Citra $=\left(\right.$ H.Kpdt $\left.{ }^{\star} 3\right)+\left(\right.$ H.Tata $\left.^{\star} 1\right)+\left(\right.$ H.Lbrjln $\left.{ }^{\star} 3\right)+$

$\left(\mathrm{H} . \mathrm{lok}^{\star} 2\right)+\left(\mathrm{H} . \mathrm{Ms} J \mathrm{ln}^{\star} 2\right)+\left(\mathrm{H}_{\mathrm{PhPel}}{ }^{\star} 2\right)$

Keterangan:

HT Citra : : Harkat total citra

H.Kpdt : Harkat Kepadatan permukiman

H.Tata : Harkat tata letak bangunan

H.Lbrjln : Harkat lebar jalan

H.MsJln : Harkat masuk jalan

H.PhPel : Harkat pohon pelindung

Setelah harkat total diketahui selanjutnya adalah melakukan klasifikasi untuk setiap parameter. Klasifikasi ini bertujuan untuk mengkelaskan blok permukiman kedalam kelas baik, sedang, atau buruk. Sebelum melakukan klasifikasi, terlebih dahulu menghitung interval kelas (range). Rumus yang digunakan adalah :

Interval Kelas $=\frac{\text { Gsor tertingi-gum terubdah }}{\text { Iumlah keles rang diinginkan }}$

Nilai tertinggi

Nilai terendah

Banyaknya klas yang diinginkan adalah 3 klas, dengan interval klas $\frac{(39-18)}{2}=8,666=9$

Angka 13 diperoleh dari penjumlahan faktor penimbang untuk klas kualitas permukiman yang disajikan dalam Tabel 7.

Tabel 7. Klasifikasi Kualitas Permukiman

\begin{tabular}{lll}
\hline Total Harkat & Klasifikasi & Klas \\
\hline $31-39$ & Kualitas Baik & I \\
$22-30$ & Kualitas Sedang & II \\
$13-21$ & Kualitas Buruk & III \\
\hline
\end{tabular}

Hasil seluruh parameter ini akan dilakukan overlay yang bertujuan untuk mengkelaskan blok permukiman kedalam kelas baik, sedang atau buruk. Metode pengharkatan pada setiap parameter penentu dilakukan dengan memberikan harkat pada setiap parameter penentu kemudian dikalikan faktor penimbang. Faktor penimbang berfungsi untuk menilai besar kecilnya pengaruh parameter terhadap panilaian kualitas permukiman. Pengharkatan ini bertujuan untuk menggambarkan perbedaan pada setiap parameter penentu untuk menilai kualitas permukiman tersebut.

\section{HASIL DAN PEMBAHASAN}

Penentuan kualitas permukiman ini ada data yang digunakan sebagai pengolahan adalah citra resolusi tinggi (Google Earth) dan peta administrasi Pulau Batam tahun 2009, pengambilan data citra resolusi tinggi dari Google Earth ini dilakukan dengan 
menggunakan software elshayal yang telah terhubung dengan Google Earth sehingga kita dapat mengambil gambaran permukaan bumi dari Google Earth yang telah terkoreksi geometrik. Berikut ini adalah parameter penentu kualitas permukiman yang digunakan pada penelitian.

\section{Parameter Kepadatan Permukiman}

Klas penentu kepadatan permukiman pada penelitian ini dibagi menjadi tiga yaitu kepadatan jarang, sedang, padat. Penentuan kepadatan permukima dilihat dengan keberadaan bangunan yang saling berdekatan. Penilaian kepadatan permukiman melalui citra diperoleh dengan mencari luas tutup atap rumah mukim dibagi dengan luas blok rumah mukim tersebut. Permukiman di Kecamatan Batam Kota didominasi oleh kepadatan tinggi dengan nilai 67.3\%. (Tabel.8)

Tabel 8. Luas Blok Permukiman Berdasarkan Kepadatan

\begin{tabular}{llll}
\hline Kriteria & Klas & $\begin{array}{l}\text { Luas } \\
(\mathrm{Ha})\end{array}$ & $\begin{array}{l}\text { Presentase } \\
(\%)\end{array}$ \\
\hline Kepadatan rendah & Jarang & 283.3 & 24.33 \\
Kepadatan sedang & Sedang & 115.3 & 9.90 \\
Kepadatan tinggi & Padat & 784.3 & 67.3 \\
\hline Sumber: Ananlisis Data, 2017 & &
\end{tabular}

Table 9 didapatkan bahwa blok permukiman di Kecamatan Batam Kota didominasi oleh permukiman dengan kepadatan tinggi dengan luas $784.3 \mathrm{Ha}$ atau 67.3 $\%$ dari luas seluruh daerah permukiman di Kecamatan Batam Kota. Bangunan yang padat membuat ruang gerak atau akses jalan menjadi sempit, ruang untuk resapan air juga berkurang sehingga permukiman dengan kepadatan yang tinggi rawan akan terjadinya genangan air jika saluran air tidak begitu baik.

Selain itu, padatnya suatu permukiman juga mengakibatkan sirkulasi di udara tersebut kurang baik karena kurangnya pepohonan dan tumbuhan hijau disekitarnya. Permukiman yang padat juga membuat berkurangnya sinar matahari yang masuk ke daerah tersebut. Kawasan dengan permukiman padat mempunyai kualitas permukiman yang buruk. Sedangkan pada permukiman dengan kepadatan rendah dengan luas 283.3 $\mathrm{Ha}$ atau $24.33 \%$ dari luas seluruh daerah permukiman di Kecamatan Batam Kota, Kota Batam.

\section{Parameter Tata Letak Bangunan}

Tata letak bangunan merupakan salah satu paremeter penentu kaulitas permukiman yang berpengaruh besar, karena semakin baik letak bangunan di suatu permukiman akan memberi nilai indah dan rapi secara visual, selain itu letak bangunan yang baik akan mempermudah jalur masuk keluarnya suatu permukiman. Penentuan nilai pada parameter tata letak bangunan dapat dilakukan dengan menginterpretasi dari citra penginderaan jauh. Tata letak bangunan dilihat dari citra dengan memperhatikan karakteristik dari susunan atau letak objek permukiman melalui pola dari permukiman tersebut. Pola keteraturan suatu permukiman ditinjau dari bangunan satu dengan bangunan lainnya pada satu blok permukiman. Tata letak bangunan dibedakan menjadi tiga pola yaitu baik diberi skor tiga (3), sedang diberi skor dua (2) dan buruk diberi skor satu (1). Pada citra dapat dilihat dengan mudah letak bangunan permukiman dengan bentuk dan pola dari bangunan tersebut. Rumah mukim yang mempunyai pola baik ditinjau dari kondisi bangunan satu dengan lainnya sama terutama yang menghadap arah ke jalan, dan luas tiap bangunan juga relatif sama. Pola sedang dapat ditinjau dari kondisi bangunan dan luas tiap bangunan relatif tidak seragam namun masih ada kemiripan bangunan satu dengan lainnya. Pola buruk dilihat dari ukuran, bentuk atap bangunan yang tidak beraturan antara satu dengan lainnya. Setelah dilakukan identifikasi blok permukiman berdasarkan tata letak bangunan, persebaran tata letak bangunan di Kecamtan Batam Kota lebih dominan bngunannya relatif baik, sedangkan tata bangunan buruk hanya ada di sebagian Kelurahan dari Kecamatan Batam Kota. Hasil perhitungan luas daerah tata letak tersaji dalam Tabel.9.

Tabel 9. Luas Blok Permukiman Berdasarkan Tata Letak Bangunan

\begin{tabular}{llll}
\hline Kriteria & Klas & $\begin{array}{l}\text { Luas } \\
(\mathrm{Ha})\end{array}$ & $\begin{array}{l}\text { Presentase } \\
(\%)\end{array}$ \\
\hline Pola Teratur & Baik & 721.2 & 61.93 \\
Pola Semi Teratur & Sedang & 383.6 & 32.9 \\
Pola Tidak Teratur & Buruk & 59.28 & 5.09 \\
\hline
\end{tabular}

Sumber: Ananlisi Data, 2017

Hasil analisis dari tata letak bangunan di Kecamatan Batam Kota di dominasi letak bangunan baik dengan luas $721.2 \mathrm{Ha}$ atau $61.93 \%$ dari luas seluruh daerah permukiman di Kecamatan Batam Kota. Faktor lahan yang masih kosong menyebabkan banyaknya bangunan yang masih tertata rapi dan baik.

\section{Parameter Lebar Jalan Masuk}

Lebar jalan masuk merupakan lebar jalan masuk yang menghubungkan jalan permukiman dengan jalan utama pada daerah permukiman tersebut. Penentuan parameter lebar jalan masuk di pilih karena dari lebar jalan ini dapat diketahui mudah tidaknya kendaraan atau transportasi untuk masuk dan keluar ke permukiman tersebut. Pemberian nilai dilakukan dengan cara mengidentifikasi penampakan obyek dari citra resolusi tinggi (Google Earth) kemudian dibagi menjadi kelas lebar $>6 \mathrm{~m}$ dengan asumsi dapat dilalui dua atau tiga mobil dalam kriteria baik dengan harkat tiga. Lebar jalan 4-6 m dikategorikan kriteria sedang dengan harkat dua, dan lebar jalan $<4$ m dikategorikan 
dalam kriteria buruk dengan harkat satu. Dari hasil identifikasi tersebut, dapat diketahui persebaran blok permukiman berdasarkan lebar jalan masuk permukiman.

\section{Parameter Kondisi Jalan Masuk}

Kondisi jalan masuk suatu permukiman merupakan keadaan jalan masuk pada permukiman. Kondisi jalan masuk dibagi menjadi tiga kelas yang terdiri dari baik, sedang dan buruk. Dasar penilaian kondisi jalan ialah pengeras jalan, apakah jalan tersebut sudah di perkeras dengan aspal dan semen atau belum. Pada lokasi penelitian, seluruh jalan memiliki kondisi yan baik, hanya beberapa bagian blok yang jalannya belum diperkeras dengan aspal dan semen.

\section{Parameter Lokasi Permukiman}

Lokasi suatu permukiman diklasifikasikan menjadi 3 kelas, yaitu: baik, sedang, dan buruk. Parameter ini didasarkan pada letak suatu permukiman terhadap sumber polusi, seperti pabrik, tempat pembuangan sampah akhir, jalan besar (arteri) serta dari daerah rawan banjir dan longsor. Penilaian parameter ini dilakukan dengan meninjau kedekatan permukiman dengan sumber polusi. Kelas baik yaitu permukiman yang lokasinya jauh dari (pabrik, jalan arteri, limbah, dll). Kelas sedang yaitu permukiman yang tidak terpengaruh secara langsung dengan sumber polusi.
Sedangkan kelas buruk yaitu permukiman yang berada di daerah sumber polusi. Asumsi yang digunakan adalah jika permukiman dekat dengan sumber polusi maka mempunyai kualitas buruk dan sebaliknya. Sumber polusi yang ada didaerah penelitian berupa polusi udara dari asap kendaraan bermotor, lokasi ini berada di sepanjang jalan arteri atau jalan raya.

\section{Parameter Pohon Pelindung}

Pohon pelindung jalan mempunyai pengaruh terhadap kenyamanan pada udara disekitar permukiman. Karena dengan ada banyaknya pohon maka udara di permukiman tersebut dan suhu di permukiman tersebut tidak begitu panas. Dalam penelitian ini pohon pelindung selain sebagai memberi nilai keindahan juga berfungsi sebagai penyaring udara disekitar permukiman sehingga udara akan terasa lebih segar. Selain itu, pohon juga berfungsi sebagai alat peneduh di sepanjang jalan. Parameter pohon pelindung hanya dibagi menjadi dua yaitu baik dan buruk, pohon pelindung dikategorikan baik jika di blok permukiman tersebut terdapat pohon, sedangkan buruk jika di blok permukiman tidak ada sama sekali pohon pelindung

\section{Hasil Identifikasi Tingkat Kualitas Permukiman}

Tingkat kualitas permukiman merupakan keadaan yang mendeskripsikan secara jelas tentang keadaan

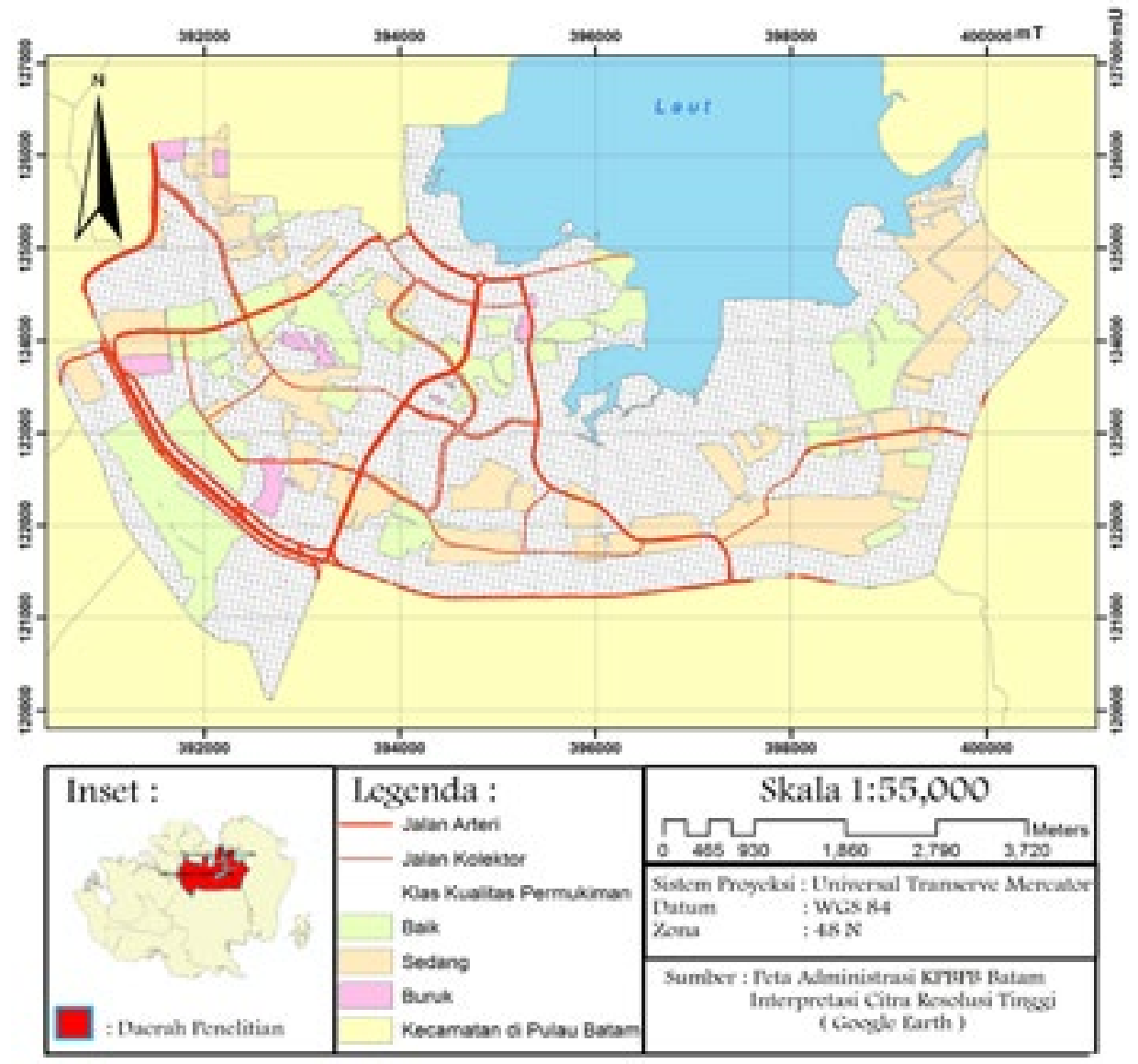

Gambar 1. Peta Kualitas Permukiman (Farizky, 2017) 
kualitas permukiman sebagai tempat mukim. Penilaian kualitas permukiman dilakukan dengan menggunakan 6 paramater penentu kualitas permukiman melalui interpretasi citra yaitu kepadatan permukiman, tata letak bangunan, lebar jalan masuk, kondisi permukaan jalan, lokasi permukiman dan pohon pelindung. Penentuan kualitas permukiman ini diperoleh dengan menghitung harkat total parameter penentu kualitas permukiman yaitu dengan menambahkan nilai hasil perkalian antara bobot masing-masing parameter yang mempengaruhi dengan nilai faktor penimbang dari parameter penentu kualitas permukiman. Setelah diketahui skor total dari masing-masing blok permukiman maka dapat diklasifikasikan klas kualitas permukimannya. Untuk luasan pada masing-masing klas dan jumlah blok pada permukiman di Kecamatan Batam Kota dapat dilihat dari Tabel 10.

Tabel 10. Luas Blok Permukiman Berdasarkan Kualitas Permukiman

\begin{tabular}{lll}
\hline Klas & Luas $(\mathrm{Ha})$ & Presentase \\
\hline$(\%)$ & & \\
Baik & 476.88 & 40.95 \\
Sedang & 650 & 55.8 \\
Buruk & 48.89 & 4.19
\end{tabular}

Sumber: Ananlsis Data, 2017

Blok permukiman di Kecamatan Kota Batam didominasi oleh kepadatan bangunan dengan kualitas permukiman sedang dengan nilai presentase 55.8\% dengan luas $650 \mathrm{Ha}$. Kualitas baik merupakan total jumlah harkat pada setiap parameter berdasarkan klasifikasi kualitas permukiman dengan nilai presentase 476.88\% dengan luas $40.95 \mathrm{Ha}$. Kualitas buruk merupakan total jumlah harkat pada setiap parameter berdasarkan klasifikasi kulaitas permukiman dengan nilai presentase $4.19 \%$ dengan luas $48.89 \mathrm{Ha}$.

Tabel 11. Tabel Luas Kualitas Pemukiman

\begin{tabular}{lll}
\hline Klas & Luas (Ha) & Presentase \\
\hline$(\%)$ & & \\
Baik & 476.88 & 40.95 \\
Sedang & 650 & 55.8 \\
Buruk & 48.89 & 4.19 \\
\hline
\end{tabular}

Sumber : Analisis 2016

\section{KESIMPULAN}

Pemetaan persebaran kualitas permukiman di Kecamatan Batam Kota berdasarkan parameter yang ditentukan yaitu kepadatan permukiman, tata letak bangunan, lebar jalan masuk, kondisi jalan masuk, lokasi permukiman, dan pohon pelindung dari interpretasi citra resolusi tinggi (Google Earth).Sebaran kualitas permukiman baik di Kecamatan Batam Kota tersebar hampir di Teluk Tering, Kelurahan Belian, dan Kelurahan Sukajadi. Dan untuk sebaran kualitas permukiman buruk juga didominasi pada daerah sekitaran Kelurahan Teluk Tering, hal ini disebabkan karena kurangya kesadaran dari masyarakat setempat dengan membangun rumah liar disekitaran jalan raya. Untuk kualitas sedang tersebar hampir diseluruh Kelurahan di Kecamatan Batam Kota, Kota Batam. Pemetaan persebaran kualitas permukiman di Kecamatan Batam Kota disajikan dalam bentuk web yang menampilkan hasil dari penelitian sesuai dengan hasil interpretasi kualitas permukiman di Kecamatan Batam Kota, Kota Batam.Tingkat kualitas permukiman di Kecamatan Batam Kota, Kota Batam didominasi tingkat kualitas sedang, kualitas baik dan kualitas buruk merupakan persebaran permukiman yang paling sedikit.

\section{DAFTAR PUSTAKA}

Ambarasakti, G. Y. (2013). Analisis Kualitas Lingkungan Permukiman Dengan Menggunakan Aplikasi Citra Penginderaan Jauh Tahun 2006 Dan 2010 Di Kecamatan Sewon Kabupaten Bantul (Doctoral dissertation, Universitas Muhammadiyah Surakarta).

Danoedoro, Projo., 2012, Pengantar Penginderaan Jauh Digital. Yogyakarta: Andi Publisher.

Ekartaji, P., Yunus, H. S., \& Rahardjo, N. (2016). Kajian Kualitas Lingkungan Permukiman di Daerah Pinggiran Kota Kasus di Desa Ngestiharjo, Yogyakarta.Majalah Geografi Indonesia, 28(1), 96102.

Indrawati, L., Hartono, H., \& Sunarto, S. (2016). Klasifikasi Pohon keputusan untuk Kajian Perubahan Penggunaan lahan Kota Semarang Menggunakan Citra Landsat TM.ETM+. Majalah Geografi Indonesia, 23(2), 109-123..

Kurniadi, A. (2014). Analisis Kualitas Lingkungan Permukiman Di Kecamatan Kotagede Kota Yogyakarta Menggunakan Citra Quickbird (Doctoral dissertation, Fakultas Ilmu Sosial).

Maru, A. C. H., \& Hidayati, I. N. (2016). Pemanfaatan Citra Quickbird dan SIG untuk Pemetaan Tingkat Kenyamanan permukiman di Kecamatan Semarang Barat Utara. Majalah Geografi Indonesia, 30(1), 1-8.

MUHAMAD, D. S. (2015). SIG untuk memetakan daerah banjir dengan metode skoring dan pembobotan (studi kasus kabupaten Jepara). Skripsi, Fakultas Ilmu Komputer.

Prahasta, E. (2009). Sistem Informasi Geografis KonsepKonsep Dasar (Perspektif Geodesi \& Informatika.

Prakoso, B. S. E., \& Muta’ali, L. (2005). Dinamika Sistem Kota-Kota Dan Pemilihan Alternatif Pusat Pertumbuhan Baru Di Propinsi Daerah Istimewa Yogyakarta. Majalah Geografi Indonesia, 19 (2005).

Ristiyono, L., Danoedoro, P., \& Marfai, M. A. (2016). Kajian Klasifikasi Berbaris Objek untuk Pemetaan Bangunan yang Beresiko Gempa Bumi di Bantul, 
Daerah Istimewa Yogyakarta. Majalah Geografi Indonesia, 30(1), 68-75.

Riswanto, E. (2009). Evaluasi Akurasi Klasifikasi Penutupan Lahan Menggunakan Citra Alos Palsar Resolusi Rendah Studi Kasus di Pulau Kalimantan. Yulianti, B. P., H Hadi Sabari Yunus, M. A., \& MA, I. B. S. (2015). Evaluasi Penataan kawasan Permukiman Kumuh: Studi Kasus: Program Peremajaan Kawasan Tegalpanggung di Kota Yogyakarta (Doctoral dissertation, Universitas Gadjah Mada). 